\title{
Manufacturing technology and strength properties of new composite joints
}

\author{
Technologia wykonania i własności wytrzymałościowe \\ nowych węzłów kompozytowych
}

\section{DANIEL K. DĘBSKI \\ KRZYSZTOF M. GOŁOŚ MAREK A. DĘBSKI*}

DOI: https://doi.org/10.17814/mechanik.2020.11.18

\begin{abstract}
The paper presents the concept, technology of manufacturing and assembly of a new metal-composite-metal joint. The presented joint can be used in many constructions, especially in lightweight supporting structures. The research of the strength properties of the analysed composite joints of load-bearing structures is also presented.

KEYWORDS: composite joints, supporting structures
\end{abstract}

W pracy przedstawiono koncepcję oraz technologię wykonania i montażu nowego węzła metal-kompozyt-metal. Węzeł ten można zastosować w wielu konstrukcjach, zwłaszcza w lekkich strukturach nośnych. Zaprezentowano także badania właściwości wytrzymałościowych analizowanych węzłów kompozytowych struktur nośnych.

SŁOWA KLUCZOWE: węzły kompozytowe, struktury nośne

\section{Introduction}

Composite materials allow designing spatially complicated supporting structures. Composites are a combination of reinforcement and polymerized saturation mixture. Reinforcement is available in the composite in the form of roving or fabric. The fabric is woven using glass, carbon, aramid or basalt fibres. The saturation mixture after the polymerization process transmits the load between individual reinforcement fibres. A very important feature of composite materials is the possibility of arranging the reinforcement in such a way that the composite structural element optimally transfers loads. The problem in manufacturing composite elements lies in the repeatability of mechanical properties. Depending on the applied manufacturing technology, equipment and experience of employees, the spread of mechanical properties may reach up to $50 \%$. When preimpregnates are used, the impact of the human factor on the properties of the composite material can be significantly reduced, but the costs of manufacturing of structural elements made of them significantly increase. Another important problem is the issue of the saturation mixture - its chemical properties in the context of the composite manufacturing process and the very low possibility of composite material recycling after the service life of the supporting structure.
Joints are sensitive areas of supporting structures. Selection of the optimal technology for a given structure to connect load-bearing structure elements is always one of the first and most important issues faced by the designer. Joints are points where concentrated forces are introduced and distributed. The selection of the optimal technology for connecting the load-bearing structure elements may determine its operation and strength $[1,2]$.

Composite construction materials, with the reinforcement in the form of roving, allowed for the search for new, durable and lightweight solutions of construction joints. The result of this search was the invention of composite joints. The concept of composite joints is an alternative solution to classical types of joints, such as welded, riveted, glued or pinned joints [2]. The composite joint can be applied to virtually all types of materials used to make elements of the supporting structure. The structure elements are connected with each other by a composite material (e.g. pipes made of steel, duralumin, composite can be connected with each other - including, in one joint, pipes made of different materials can be connected).

In some cases the supporting structures of the composite joints proved to be the only ones that could be used.

\section{The concept and technology of manufacturing new composite joints}

The concept of composite joints is based on connecting the load-bearing elements with a composite material which transfers the load from one load-bearing element to another [1-3]. In the case of using reinforcement in the form of roving saturated with the saturated mixture, we can obtain a connection (structural joint) analogous to anatomical connections or connections which are known from the times of the original man. The precursor of the technology of composite joints in Poland is Krzysztof Kotliński (a graduate of the Faculty of Automotive and Construction Machinery Engineering of the Warsaw University of Technology) [1, 2].

\footnotetext{
* Dr inż. Daniel K. Dębski, daniel.debski@pw.edu.pl, https://orcid.org/0000-0002-3765-1232 - Warsaw University of Technology, Faculty of Automotive and Construction Machinery Engineering, Institute of Machine Design Fundamentals, Warsaw, Poland Prof. dr hab. inż. Krzysztof M. Gołoś, krzysztof.golos@pw.edu.pl, https://orcid.org/0000-0003-1534-575X - Warsaw University of Technology, Faculty of Automotive and Construction Machinery Engineering, Institute of Machine Design Fundamentals, Warsaw, Poland

Dr inż. Marek A. Dębski, e-mail: dedal_@wp.pl - retired employee of the Łukasiewicz Research Network - Institute of Aviation, Warsaw, Poland
} 
An example of a composite joint connecting two coaxial duralumin tubes is shown in Fig. 1. Carbon roving was used as reinforcement. The matrix was a saturated mixture in the form of epoxy resin Epidian 53 and hardener Z-1. The composite $(A)$ is wrapped around duralumin sleeves $(B)$ riveted with one-sided rivets to both pipes. On the surface of the pipes you can see a protective substance for the pipe material.

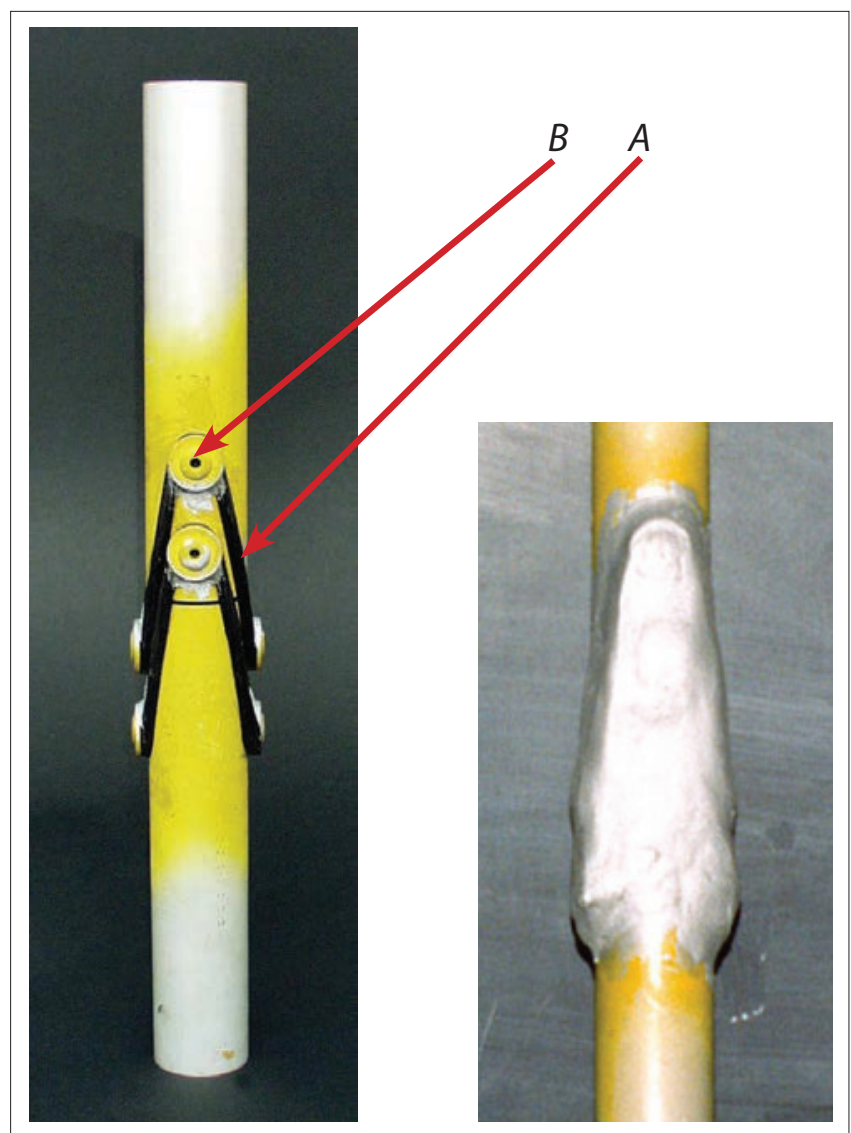

Fig.1. Composite joint with carbon roving, composite joint filled with material with silica filler reinforcement

The joint shown in Fig. 1 on the right may be subject to complex loading (tensile-pressing + twisting) after placing appropriate ends on the pipes and filling the space between the pipes of the composite with the reinforcement in powder form.

\section{Composite strength}

With axial load, parallel to the fibre direction, the coefficient of proportionality between average stress $\sigma$ and mean relative elongation $\varepsilon$ is the modulus of elasticity of the composite material $E_{K}$ which is calculated according to the linear rule of mixtures, knowing the modulus of longitudinal elasticity of individual components [2]. For the considered load case in the linear range, the modulus of elasticity of the composite can be defined as:

$$
E_{\mathrm{K}}=E_{\mathrm{W}} V_{\mathrm{W}}+E_{\mathrm{P}}\left(1-V_{\mathrm{W}}\right)
$$

where: $E_{\mathrm{K}}, E_{\mathrm{W}}, E_{\mathrm{P}}$ - modulus of composite elasticity, reinforcement fibres and matrix; $V_{\mathrm{W}}$ - the volume content of fibres in the composite.
In the analysed range of elastic deformations, the stresses can be calculated according to the rule of mixtures:

$$
\sigma_{\mathrm{K}}=\sigma_{\mathrm{W}} V_{\mathrm{W}}+\sigma_{\mathrm{P}}\left(1-V_{\mathrm{W}}\right)
$$

where: $\sigma_{\mathrm{K}}, \sigma_{\mathrm{W}}, \sigma_{\mathrm{P}}$ - stresses of the composite, fibres and polymer.

When the load increases, the polymer deforms in a visco-elastic way, and the fibres in an elastic way. Then, the equation (1) is replaced by the equation (2) of form:

$$
E_{\mathrm{K}}=E_{\mathrm{W}} V_{\mathrm{W}}+E_{\mathrm{P}}\left|\frac{\mathrm{d} \sigma_{\mathrm{n}}}{\mathrm{d} \varepsilon_{\mathrm{t}}}\right|\left(1-V_{\mathrm{W}}\right)
$$

In this equation, the expression $\left|\mathrm{d} \sigma_{\mathrm{n}} / \mathrm{d} \varepsilon_{\mathrm{t}}\right|$ describes a non-linear increase in the curve of the unreinforced polymer matrix to its total extension $\left(\varepsilon_{\mathrm{t}}\right)$, corresponding to the total extension of the composite $\left(\varepsilon_{\mathrm{K}}\right)$. In order to use the high strength of the fibres it is necessary that the extension $\left(\varepsilon_{\mathrm{mP}}\right)$ of the polymer matrix at breaking is at least equal to the extension $\left(\varepsilon_{\mathrm{mw}}\right)$ of the reinforcing fibres:

$$
\varepsilon_{\mathrm{mP}}>\varepsilon_{\mathrm{mW}}
$$

Thus, the tensile strength of the composite $\left(R_{\mathrm{mK}}\right)$ can be presented in the form:

$$
R_{\mathrm{mK}}=R_{\mathrm{mW}} V_{\mathrm{W}}+\sigma_{\mathrm{P}}\left(1-V_{\mathrm{W}}\right)
$$

where: $R_{\mathrm{mW}}$ - fibre tensile strength.

Similarly, to make the strength of the composite greater than that of the polymer $\left(R_{\mathrm{mP}}\right)$ the relationship occurs:

$$
R_{\mathrm{mK}}\left(=R_{\mathrm{mw}} V_{\mathrm{W}}+\sigma_{\mathrm{P}}\left(1-V_{\mathrm{W}}\right)\right)>R_{\mathrm{mP}}
$$

With very low fibre content, the composition equation (5) is not valid and the condition of loss of cohesion of the composite represents the dependence:

$$
R_{\mathrm{mK}}=R_{\mathrm{mW}} V_{\mathrm{W}}+\sigma_{\mathrm{P}}\left(1-V_{\mathrm{W}}\right) \geq R_{\mathrm{mP}}\left(1-V_{\mathrm{W}}\right)
$$

After transformations one can get:

$$
R_{\mathrm{mK}}=R_{\mathrm{mW}}\left[V_{\mathrm{W}}+\frac{E_{\mathrm{P}}}{E_{\mathrm{W}}}\left(1-V_{\mathrm{W}}\right)\right]
$$

Since for composites the $E_{\mathrm{p}} / E_{\mathrm{W}}$ ratio is very small, it can be omitted, especially for composites with a high content of reinforcing fibres. We will then get:

$$
R_{\mathrm{mK}}=R_{\mathrm{mW}} V_{\mathrm{W}}
$$

With high $V_{W}$ levels, however, the possibility of damage to the composite due to insufficient load transmission in the fibre-matrix-fibre ratio must be considered. 


\section{Experimental testing}

Composite joints have extremely beneficial mechanical properties revealed during static tensile and fatigue tests. A number of different tests were conducted on the experienced nodes with glass, carbon and Kevlar roving [1-4]. Joints connecting the coaxial pipes and flat duralumin girders were tested (Fig. 2).

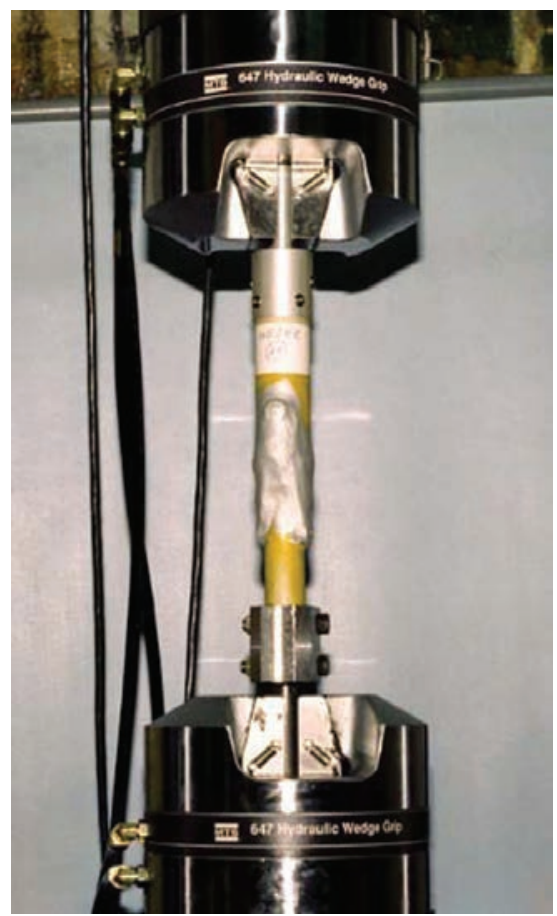

Fig. 2. Model tests of a composite joint connecting duralumin pipes

The course of destruction of the composite joint is gradual and not jumping. Destruction of the joint is signalled by large deformations while maintaining the ability of the joint to carry an increasing load, which is an extremely important feature of composite joints made with this technology. During the process of destroying the connection, the next, the most intense bands of the composite are torn off - which is, among others, the effect of manual joining of structural elements with saturated roving.

The following diagram shows the course of the static tensile test sample with glass roving.

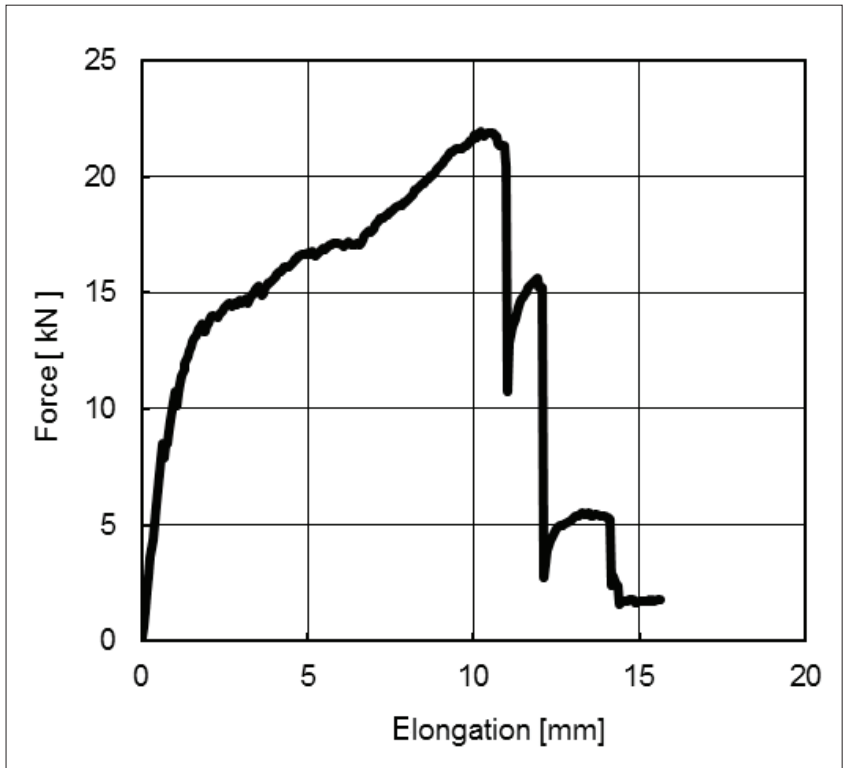

Fig. 3. Course of static tensile test

The composite joints were also subjected to fatigue tests [1]. During the fatigue tests at the assumed load levels, the glass roving joint did not fail after mapping 100,000 load cycles, while the Kevlar and carbon node were destroyed by fatigue cracking of the connecting elements, i.e. the duralumin tubes in the area of the attachment holes of the anchors. The load for fatigue testing was assumed to be about $75 \%$ of the allowable load $[1,3]$. For the evaluation of the residual strength, a tensile test was carried out, as a result of which no visible decrease in static strength was observed.

Positive results of strength tests of model composite joints [1-3] allowed for the development and execution of a spatially complex supporting structure in the form of a truss made of duralumin tubes of different diameters. The pipes were connected by composite joints with glass reinforcement. The truss passed the fatigue tests according to the test program.

\section{Conclusions}

The presented concept of composite nodes allows to construct a node in an optimal way to carry a given

TABLE. Results of static tensile tests of composite joints

\begin{tabular}{|c|c|c|c|c|c|c|c|}
\hline Node & $\begin{array}{l}\text { Joint } \\
\text { (reinforcement type) }\end{array}$ & $\begin{array}{l}\text { Extension } \\
\text { scope, kN }\end{array}$ & $\begin{array}{l}\text { Failure } \\
\text { load } P_{\mathrm{n}} \text {, } \\
\quad \mathrm{kN}\end{array}$ & $\begin{array}{l}\text { Destruction } \\
\text { type }\end{array}$ & $\begin{array}{l}\text { Joint stresses under } \\
\text { destructive loads, } \\
\text { MPa }\end{array}$ & $\begin{array}{l}\text { Share of joint } \\
\text { extension in sample } \\
\text { extension }\end{array}$ & $\begin{array}{l}\text { Safety } \\
\text { factor } \\
(3) /(2)\end{array}$ \\
\hline & (1) & (2) & (3) & (4) & (5) & (6) & (7) \\
\hline 1 & $\begin{array}{l}\text { Glass } \\
\text { (S0-1) }\end{array}$ & 8.7 & 22 & $\begin{array}{l}\text { material's } \\
\text { composite } \\
\text { failure }\end{array}$ & 314 & 0.66 & 2.5 \\
\hline 2 & $\begin{array}{l}\text { Kevlar } \\
\text { (K0-1) }\end{array}$ & 11 & 27 & $\begin{array}{l}\text { material's } \\
\text { composite } \\
\text { failure }\end{array}$ & 386 & 0.54 & 2.5 \\
\hline 3 & $\begin{array}{l}\text { Carbon } \\
\text { (W0-1) }\end{array}$ & 11 & 27.5 & hook rupture & 393 & 0.38 & 2.5 \\
\hline
\end{tabular}



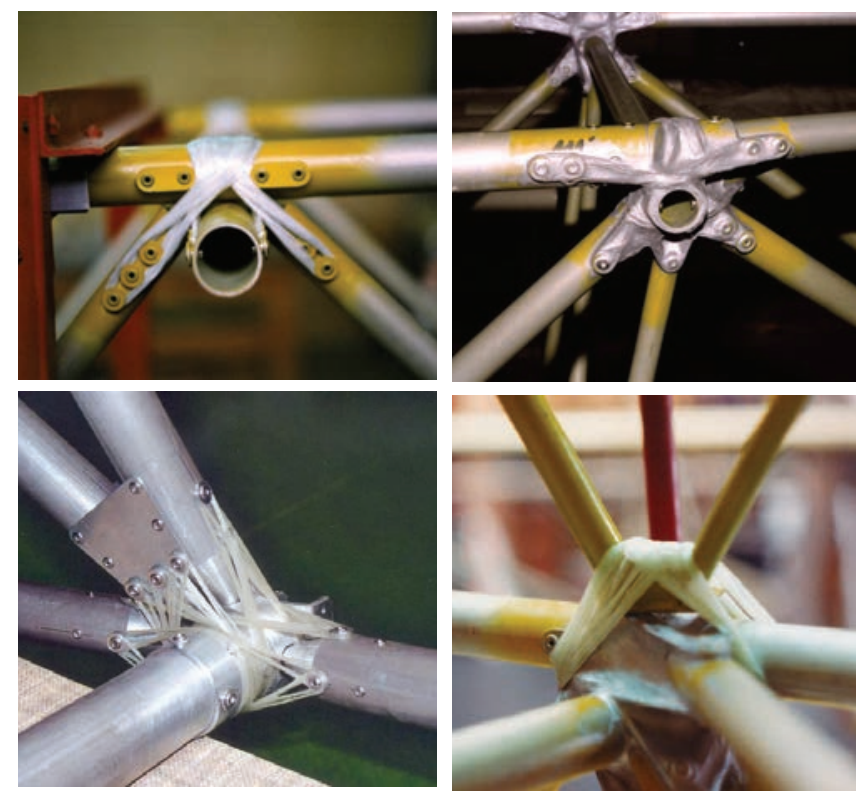

Fig. 4. Joints in a complex truss system

load. Composite joints can be used in very complex, spatial supporting structures [1], e.g. as shown in Fig. 4. The destruction of one of the truss tubes does not necessarily mean the destruction of the entire joint. Thanks to this technology, structural elements made of different materials can be connected.
The concept of composite joints is characterized by simple technology. The supporting structure with composite joints (e.g. truss with duralumin tubes) can be made already in relatively primitive conditions. The equipment is simple and the employees are not required to be highly qualified. Defectoscopic checks are not used in this type of connection. Thanks to composite joints we avoid the characteristic for welded constructions warping due to the relaxation of internal stresses created during the welding process.

\section{REFERENCES}

[1] Dębski M., Gołoś K., Dębski D. "Composite Joints of Aerostructures". Transactions of the Institute of Aviation. 170-171 (2002): 3-27. ISSN: 0509-6669.

[2] Dębski M., Dębski D. „Wybrane zagadnienia wytrzymałości zmęczeniowej konstrukcji lotniczych". Warszawa: Biblioteka Naukowa Instytutu Lotnictwa, 2014. ISBN: 978-8363539-06-1.

[3] Dębski M., Gołoś K., Dębski D., Kaźmierski J. “Fatigue analysis tools for aerostructures". Warsaw: Scientific Library of the Institute of Aviation, 2018. ISBN: 978-83-63539-46-7.

[4] Starczewski Z. (ed.). „Redukcja drgań w układach wirujacych $i$ ustrojach nośnych poprzez monitorowanie właściwości sprężysto-tłumiących za pomoca materiałów «inteligentnych» $i$ «kompozytowych»". Warszawa: Politechnika Warszawska, 2014. 